\title{
Sakız Yutma ile Karakterize Bir Pika Olgusu
}

\author{
A Pica Case with Chewing Gum Swallowing
}

Mehmet Hamdi ORUM'10

${ }^{1}$ Kahta State Hospital Psychiatry Department, Adiyaman, Turkey

ÖZ

\begin{abstract}
Amaç: Pika, besleyici olmayan maddelerin en az bir aylık bir süre boyunca sürekli olarak yenmesi olarak tanımlanır ve bazen birkaç ay sürer ve kendiliğinden düzelir, nadiren de yetişkinliğe kadar devam edebilir. Burada, psikiyatrik komorbiditesi olan sakız yutma ile karakterize bir pika olgusunu ele aldık.
\end{abstract}

Anahtar Kelimeler: Pika, Sakız yutma, Psikiyatrik komorbidite.

ABSTRACT

Objective: Pica is characterized as persistent eating of non-nutritive substances for a period of at least one month and sometimes lasts for several months and resolves spontaneously, rarely can continue until adulthood. Herein, we presented a pica case characterized by chewing gum swallowing who had psychiatric comorbidity.

Key words: Pica, Gum swallowing, Psychiatric Comorbidity.

\section{INTRODUCTION}

Pica is characterized as persistent eating of non-nutritive substances for a period of at least one month according to the DSM-5 criteria (1). It has been an enigma ever since it was first documented by Hippocrates in the fourth century BC. The name derives from the Latin word for magpie (pica pica), a bird that collects and/or ingests a wide variety of objects (2). For the diagnosis, the consumption of non-food substances should be incompatible with the level of development and should not be considered culturally supported or socially acceptable (3). Pica sometimes lasts for several months and resolves spontaneously, rarely can continue until adulthood. In the studies, pica varieties are known as ice, ice cream, soil, clay, mud, tomato, raw rice, aspirin, coke. Another rare pica is chewing gum swallowing (4). In this study, we presented a female patient with gum swallowing.

\section{CASE PRESENTATION}

The patient was married (8 years), unemployed female has three children born in 1992. She was admitted to the psychiatric outpatient clinic with complaints of gum swallowing, anxiety and adjustment problems with her husband and diagnosed with pica plus generalized anxiety disorder according to DSM-5 (1). After 4-5 years of age, began to eat soil, coal, lime. She consumes lots of sweets and products like coke and hamburger. Two years ago, the first time, she has started to swallow a small piece of chewing gum after balloon. In this way he 
finished a gum 8-10 times after making the balloon. It consumes an average of 7-8 gums per day. In the first 5 months of her last pregnancy, she left this habit because of nausea, but then he started again. This complaint periodically increased or decreased. She had no past medical history and no family history. There was no history of substance use (e.g., cigarette, alcohol, opioid, cannabis). Physical examination of other systems was unremarkable. Laboratory findings suggested iron deficiency: Haemoglobin $(\mathrm{Hb}) 11.4 \mathrm{~g} / \mathrm{dL}$, Hct 35.2\%, mean corpuscular volume (MCV) $72.7 \mathrm{fL}$, Red Blood Cell Distribution Width_Coefficent of Variation (RDW) $15.1 \%$, serum iron $13.9 \mathrm{mcg} / \mathrm{dL}$ (22-184), iron binding capacity $329.8 \mathrm{mcg} / \mathrm{dL}$ (250-400), ferritin $22.83 \mathrm{ng} / \mathrm{mL}(7-140)$, and transferrin saturation $6.7 \%$ (> 15\%). After the internal medicine consultation, iron treatment was started. Sertraline was started at $50 \mathrm{mg} /$ day per oral (PO) for anxiety symptoms. In the fifth month of iron therapy and psychiatric treatment, in the patient whose anxiety symptoms were improved under antidepressant and cognitive behavioural psychotherapy (cognitive error identification, alternative thought generation, problem solving, activity planning, mastery and pleasure techniques), pica symptoms were significantly regressed but not completely disappeared. The patient has gained alternative coping mechanisms to cope with psychological stressors.

\section{DISCUSSION}

This case report was evaluated as a case of pica characterized by swallowing gum. Pica is thought to be the result of complex interaction of physiological and behavioural factors (5). Pica is thought to be related to iron (6) deficiency. Therefore, pica symptoms have been shown to decrease with treatment of underlying deficiency. However, comorbidity of psychiatric disorders may affect the emergence and maintenance of these symptoms. Hata et al. (7) indicated that the pica could be a view of underlying depression. Mehra et al. (8) reported a case of a female patient using psychosocial stressors and the picnic to cope with depression. In our patient, the psychiatric disease ground in the patient was thought to be effective in gaining chronicity rather than the formation of pica. Addition of psychiatric treatment to iron deficiency treatment and psychoeducation are thought to increase success rates. Further studies are needed to clarify the extent and the extent of underlying mechanisms.

Conflict of Interest and Financial Disclosure: None declared.

\section{REFERENCES}

1. American Psychiatric Association. (2013). American Psychiatric Association: Diagnostic and Statistical Manual of Mental Disorders, (p. 81). Arlington: American Psychiatric Association.

2. Bogdanovic, M., Alempijevic, D., Curcic, D., \& Durmic, T. (2018). A fatal outcome of pica syndrome: an unusual case of delayed mortality. The American journal of forensic medicine and pathology, 39(3), 261-263.

3. Edwards, C. H., Johnson, A. A., Knight, E. M., Oyemade, U. J., Cole, O. J., Westney, O. E., et al. (1994). Pica in an urban environment. The Journal of nutrition, 124(suppl_6), 954S-962S. 
4. Comba, A., Çaltepe, G., Yüce, Ö., Rızalar, R., \& Gazi Kalaycı, A. (2014). Karında Kitlenin Nadir Bir Nedeni: Trikobezoar. Journal of Current Pediatrics/Guncel Pediatri, 12(1).

5. Bhatia, M. S., \& Kaur, N. (2014). Pagophagia-A common but rarely reported form of pica. Journal of clinical and diagnostic research: JCDR, 8(1), 195.

6. Barton, J. C., Barton, J. C., \& Bertoli, L. F. (2019). Pagophagia in men with irondeficiency anemia. Blood Cells, Molecules, and Diseases, 77, 72-75.

7. Hata, T., Mandai, T., Ishida, K., Ito, S., Deguchi, H., \& Hosoda, M. (2009). A rapid recovery from pagophagia following treatment for iron deficiency anemia and TMJ disorder accompanied by masked depression. Kawasaki Med J, 35(4), 329-32.

8. Mehra, A., Sharma, N., \& Grover, S. (2018). Tekrarlayan Majör Depresif Bozukluğu Olan Bir Kadın Hastada Pagofaji: Bir Olgu Sunumu ve Literatür Derlemesi. Turk Psikiyatri Dergisi, 29(2). 